KONSTAN
JURNAL FISIKA DAN PENDIDIKAN FISIKA
Volume 3, Nomor 2, Desember 2018
$\begin{array}{r}\text { E-ISSN : 2460-9129 dan P-ISSN : 2460-9110 } \\ \text { http://jurnalkonstan.ac.id/index.php/jurnal }\end{array}$

\title{
PENGARUH PENERAPAN BLENDED LEARNING BERBASIS SCHOOLOGY TERHADAP KEMAMPUAN BERPIKIR KRITIS SISWA
}

\author{
Wiwik Suci Ambar Ningsih ${ }^{1}$, Wayan Suana ${ }^{2}$, Nengah Maharta ${ }^{3}$ \\ ${ }^{1,2,3}$ Program Studi Pendidikan Fisika, Universitas Lampung
}

\section{Info Artikel}

Sejarah Artikel:

Diterima November 2018

Disetujui November 2018

Dipublikasikan Desember 2018

\section{Kata Kunci:}

Blended learning,

Schoology,

Kemampuan berpikir kritis.

\begin{abstract}
Abstrak
Penelitian ini bertujuan untuk melihat pengaruh penggunaan Blended learning berbasis schoology terhadap kemampuan berpikir kritis siswa. Pada penelitian ini menggunakan design penelitian Non-Equivalent Control Group Design. Selanjutnya populasi yang digunakan dalam penelitian ini yaitu seluruh siswa XII IPA SMA Negeri 5 Metro dengan sampel yang terpilih melalui teknik purposive sampling yaitu XII IPA 1 dan 2. Teknik pengumpulan data yang digunakan berbentuk tes pilihan jamak untuk mengukur kemampuan berpikir kritis siswa. Teknik analisis data menggunakan Uji $N$-Gain dan uji Independent Sample T-test . Nilai rata-rata $N$ gain kemampuan berpikir kritis pada kelas ekperimen sebesar 0,43 dengan kategori sedang, sedangkan kelas kontrol dengan kategori rendah bernilai 0,10. Berdasarkan hasil dari uji Independent Sample T-test, nilai Asymp. Sig. (2Tailed) kurang dari 0,05 yaitu sebesar 0,000, maka $\mathrm{H}_{0}$ ditolak. Jadi terdapat perbedaan rata-rata kemampuan berpikir kritis siswa kelas eksperimen dan kelas kontrol secara siginifikan.Artinya penerapan blended learning berbasis schoology memberikan pengaruh yang siginifikan terhadap kemampuan berpikir kritis.
\end{abstract}

(C) 2018 Universitas Islam Negeri Mataram 


\section{PENDAHULUAN}

Pembelajaran yang diterapkan pada kurikulum 2013 edisi revisi menuntut siswa untuk dapat cakap berpikir tingkat tinggi (High Order Thingking). Sistem pembelajaran dirancang sesuai dengan tuntutan abad ke-21 yang menekankan kompetensi berbasis pada 4C meliputi berpikir kritis (critical thinking), kerjasama (collaboration), komunikasi (communication), dan kreativitas (creativity). Berdasarkan hasil survei TIMSS bahwa siswa Indonesia menduduki peringkat 45 dari 48 negara [1]. Selain itu juga keikutsertaan Indonesia dalam PISA 2015 mendapatkan hasil bahwa Indonesia berada pada peringkat 62 dari 70 negara dengan rata-rata skor yang diperoleh adalah 403 [2]. Hasil survei tersebut menunjukan bahwa kemampuan siswa Indonesia masih berada pada level kognitif rendah dan belum memiliki keterampilan berpikir kritis .

Kenyataanyan itu juga terindikasi pada pembelajaran fisika yang dilakukan di SMA N 5 Metro. Berdasarkan hasil wawancara dengan salah satu guru fisika kelas XII IPA bahwasanya siswa kurang berminat untuk mengikuti pembelajaran dikarenakan siswa dibebaskan untuk memilih satu saja mata pelajaran IPA untuk ujian nasional. Siswa yang tidak memilih pelajaran fisika akan bermalas-malas mengikuti pembelajaran. Materi pembelajaran yang cukup komplek membuat guru kekurangan waktu mengajar di sekolah namun tersedianya fasilitas internet disekolah juga tidak dimanfatkan untuk proses pembelajaran.

Pada hakikatnya dengan adanya kemajuan teknologi saat ini, sistem pembelajaran dapat diimplementasikan yaitu blended learning. Blended learning merupakan pembelajaran tatap muka dan online learning yang dapat meningkatkan aktivitas siswa [3]. Keunggulan blended learning dapat mengeliminasi seminimal mungkin kekurangan antara model pembelajaran tatap muka dan online learning [4]. Melalui blended learning pembelajaran dilakuakan sebanyak mungkin dengan cara saling berinteraksi tanpa mengenal latar belakang dan lokasinya dimana saja dan kapan saja [5].

Terdapat tiga tipe blended learning meliputi online learning -tatap muka, tatap muka- online learning dan online learning-tatap muka-online learning. Pertemuan tatap muka biasanya digunakan untuk menjelaskan materi pembelajaran dan pemecahan masalah [6] atau untuk memahami konsep pada siswa [7]. Kemudian pada tipe tatap muka - online, bahan ajar yang diberikan pada saat pertemuan tatap muka siswa diberikan penjelasan terlebih dahulu dan melakukan proses diskusi kemudian mengambil kesimpulan dengan cara berpikir kritis melalui online learning [8]. Selanjutnya tipe "online learning - tatap muka - online learning" dalam setiap siklus pembelajaran. Online learning dilakukan sebelum dan sesudah pembelajaran tatap muka untuk melanjutkan diskusi yang dibimbing guru. Diskusi online dapat dilakukan tidak serempak pada waktu yang sama tetapi dengan ketersediaan siswa [9].

Salah satu model pembelajaran yang mendukung penerapan blended learning yaitu model inkuiri terbimbing dengan tahapan orientasi, merumuskan masalah, membuat hipotesis, mengumpulkan data, menganalisis data atau menguji hipotesis dan menarik kesimpulan [10]. Pembelajaran menggunakan inkuiri terbimbing dengan Blended learning lebih efektif daripada hanya inkuiri tanpa online learning [11]. Inkuiri terbimbing sangat direkomendasikan untuk diterapkan 
pada pembelajaran fisika [12]. Melalui inkuiri terbimbing peserta didik dihadapkan pada aktivitas ilmiah [13]. Pembelajaran yang berdasarkan metode ilmiah dapat mengembangkan kemampuan berpikir kritis [14].

Kemampuan berpikir kritis merupakan cara berpikir reflektif dan beralasan yang difokuskan kepada pengambilan keputusan untuk memecahkan masalah [15]. Berpikir kritis memiliki enam unsur-unsur dasar yang harus dipenuhi yang di singkat dengan FRISCO ( focus, reasons, infrerence, situation, clarity, overview) [16]. Berpikir kritis memiliki peranan yang penting dalam dunia pendidikan dan merupakan tujuan utama dalam pembelajaran [17]. Indikator berpikir kritis yang diungkapkan meliputi memfokuskan pertanyaan, menganalisis argumen, mempertimbangkan apakah sumber dapat dipercaya atau tidak, mengidentifikasi asumi-asumsi dan menentukan tindakan [16].

Kemampuan berpikir kritis dapat ditingkatkan melalui model pembelajaran yang beragam seperti melakukan grup eksperimen dan grup diskusi yang terkontrol [18]. Grup diskusi dapat dilakukan pada saat online learning melalui media Learning Management System (LMS) untuk meningkatkan aktivitas siswa [3]. LMS adalah platform atau aplikasi perangkat lunak atau teknologi berbasis web [19]. Pembelajaran Blended learning berbantuan LMS lebih efektif daripada pembelajaran konvensional [20]. LMS berbasis schoology dapat digunakan guru dan peserta didik untuk membangun komunitas pembelajaran yang kolaboratif [21]. Schoology dapat digunakan untuk memanfaatkan waktu saat di luar jam sekolah [22]. Pemandu atau guru dapat berkolaborasi dengan siswa pada saat melakukan pembelajaran online learning [23].

Berdasarkan pada teori-teori tersebut blended learning dapat dijadikan sebagai penelitian dengan tujuan untuk mengetahui pengaruh penggunaan blended learning berbasis schoology pada materi listrik dinamis terhadap kemampuan berpikir kritis siswa.

\section{METODE PENELITIAN}

Metode yang digunakan dalam penelitian ini yaitu Quasi Eksprimental dengan menggunakan desain penelitian Non-Equivalent Control Group Design yang dapat dibaca pada Tabel 1.

Tabel 1. Desain Eksperimen Non-Equivalent Control Group Design

\begin{tabular}{llll}
\hline Kelas & Pretest & Perlakuan & Posttest \\
Eksperimen & $O_{1}$ & $X_{1}$ & $O_{2}$ \\
Control & $O_{3}$ & $X_{2}$ & $O_{4}$ \\
\hline
\end{tabular}

Pada kelas eksperimen dan kontrol diberikan prettest. Kelas eksperimen dilakukan pembelajaran inkuiri dengan sistem Blended learning yang dikembangkan oleh Wijayanti [24], dengan tipe blended learning yaitu online learning - tatap muka - online learning. Kelas kontrol hanya dilakukan pembelajaran konvensional dengan tatap muka saja. Setelah diberikan perlakuan pada akhir pembelajaran diberikan posttest pada kedua kelas tersebut untuk melihat hasinya. Hasil dari posttest tersebut digunakan sebagai pembanding untuk melihat 
pengaruh penggunaan blended learning dan pembelajaran konvensional terhadap kemampuan berpikir kritis siswa.

Populasi pada penelitian ini yaitu seluruh siswa kelas XII SMA Negeri 5 Metro dengan menggunakan dua sampel. Sampel yang digunakan kelas eksperimen dan kontrol yaitu XII IPA 1 dan XII IPA 2 dengan jumlah siswa masing 32 siswa dan 33 siswa.

Variabel bebas dalam penelitian ini yaitu penggunaan blended learning berbasis schoology dan variabel terikatnya yaitu kemampuan berpikir kritis siswa. Selanjutnya, Instrumen yang digunakan adalah tes dan angket. Pada instrument tes ini dalam bentuk pretest dan posttest dengan soal indikator berpikir kritis yang terdiri dari 20 soal pilihan ganda. Soal tersebut yang sudah teruji validitasnya menggunakan Uji Person Correlation dan realibilitas dengan metode cronbach's alpha. Angket diberikan setelah selesai keseluruhan proses pembelajaran untuk melihat pengaruh blended learning pada siswa.

Analisis kategori hasil kememampuan berpikir kritis siswa dapat diuji dengan uji $\mathrm{N}$-Gain yang menggunakan persamaan :

$$
N-\text { gain }(g)=\frac{S_{\text {post }}-S_{\text {pre }}}{S_{\text {max }}-S_{\text {pre }}}
$$

Keterangan:

$g=N$-Gain

$\mathrm{S}_{\mathrm{post}}=$ Skor posttest

$\mathrm{S}_{\mathrm{pre}}=$ Skor pretest

$\mathrm{S}_{\max }=$ Skor maksimum

Selanjutnya, dari hasil nilai $N$-Gain tersebut diujikan normalitasnyadengan uji statistik parametrik melalui program SPSS dengan uji Kolmogorov-Smirnov. Jika dari hasil uji normalitas didapatkan nilai Asym.Sig > 0,05 nilai tersebut dapat dikatakan terdistribusi normal. Uji beda dapat dilakukan dengan syarat apabila sampel berdistribusi normal dan homogen, menggunakan uji Independent Sampel T Test, dimana jika Ho diterima maka nilai Asymp. Sig. (2-tailed) $>0,05$. Uji beda tersebut dilakukan untuk mengetahui ada atau tidaknya perbedaan rerata antara kelas eksperimen dan kelas kontrol terhadap kemampuan berpikir kritis siswa.

\section{HASIL DAN PEMBAHASAN \\ Hasil Penelitian}

Pada kelas eksperimen pembelajaran dilakukan secara blended learning berbasis schoology dengan model inkuiri terbimbing. Pembelajaran dilakukan dengan tatap muka sebanyak 4 kali pertemuan dan online learning sebanyak 8 kali pertemuan dimana 4 kali sebelum dan sesudah tatap muka dengan waktu 60 menit. Pada kelas kontrol pembelajaran hanya tatap muka sebanyak 4 kali pertemuan. Hasil yang diperoleh dalam penelitian ini yaitu data kuantitatif dari nilai test yang digunakan untuk mengukur kemampuan berpikir kritis siswa.

Hasil uji instrument tes dilakukan kepada siswa yang telah mempelajari materi listrik dinamis pada 70 responden dengan jumlah soal sebanyak 20 soal pilihan jamak. Nilai yang didapatkan Asym.Sig $>0,05$ sehingga semua soal 
tersebut bersifat valid dan layak untuk digunakan. Hasil realibilitas soal dengan nilai cronbach's alpha yaitu 0,876 yang memiliki nilai sig $>0.05$ dan dapat dinyatakan butir-butir soal tersebut memiliki kriteria realibilitas yang sangat tinggi.

Instrumen tes tersebut digunakan pada pretest dan posttest untuk kelas eksperimen dan kelas kontrol. Pretest dan posttest dilakukan untuk melihat peningkatan nilai pada siswa yang dapat digunakan untuk mengukur kemampuan berpikir kritis siswa. Data pretest dan posttest siswa yang dapat dibaca pada Tabel 2.

Tabel 2. Data pretest dan posttest

\begin{tabular}{llllll}
\hline \multirow{2}{*}{ No } & Parameter & \multicolumn{2}{l}{ Kelas Eksperimen } & Kelas Kontrol & \\
\cline { 3 - 5 } & & Pretest & Posttest & Pretest & Posttest \\
\hline 1 & $\begin{array}{l}\text { Jumlah } \\
\text { Siswa }\end{array}$ & 32 & 32 & 33 & 33 \\
\hline 2 & Rata-Rata & 33,28 & 62,34 & 35,91 & 44,09 \\
\hline 3 & $\begin{array}{l}\text { Nilai } \\
\text { Tertinggi }\end{array}$ & 50,00 & 75,0 & 55,0 & 55,0 \\
\hline 4 & $\begin{array}{l}\text { Nilai } \\
\text { Terendah }\end{array}$ & 20,00 & 35,0 & 10,00 & 25,0 \\
\hline
\end{tabular}

Berdasarkan dari data pretest dan posttest dapat dikatakan bahwa nilai ratarata posttest kelas eksperimen memiliki lebih tinggi daripada nilai rata-rata kelas kontrol setelah diberikan perlakuan yang berbeda. Selanjutnya, data tersebut dapat digunakan untuk mengetahui kemampuan berpikir kritis siswa melalui uji $\mathrm{N}$-Gain. Data hasil uji $N$-Gain dapat dibaca pada Tabel 3.

Tabel 3. Data Rata-Rata N-Gain Kemampuan Berpikir Kritis

\begin{tabular}{llll}
\hline No & Perolehan Skor & Kelas Eksperimen & $\begin{array}{l}\text { Kelas } \\
\text { Kontrol }\end{array}$ \\
\hline 1 & Gain Tertinggi & 55,00 & 35,00 \\
\hline 2 & Gain Terendah & 00,00 & $-25,00$ \\
\hline 3 & Rata-rata Gain & 29,06 & 8,18 \\
\hline 4 & Rata-rata $N$-Gain & 0,43 & 0,10 \\
\hline 5 & Kategori & Sedang & Rendah \\
\hline
\end{tabular}

Berdasarkan hasil uji N-Gain tersebut dapat dikatakan kemampuan berpikir kritis siswa kelas eksperimen berkeriteria sedang namun pada kelas kontrol kemampuan berpikir kritis siswa berkriteria rendah. Data hasil uji $N$-Gain tersebut diuji normalitas dengan uji statistik parametrik yaitu uji Kolmogorov-Smimov . Nilai uji tersebut didapatkan Asymp. Sig (2-tailed) >0,05 yaitu 0,924 maka sampel tersebut dapat dinyatakan berdistribusi normal. Selanjutnya dilakukan uji Levene's didapatkan siginifikansi 0,210 yang berarti sig >0,05, dapat disimpulkan bahwa kedua kelompok data mempunyai varian yang sama disebut dengan homogen. 
Berdasarkan sampel yang digunakan bersdistribusi normal dan homogen maka dilakukan uji Independent Sampel T-test untuk mengetahui ada tidaknya perbedaan rata-rata kemampuan berpikir kritis siswa pada kelas eksperimen dan kontrol. Hasil Uji Independent Sampel T-test ditampikan pada Tabel 4.

Tabel 4. Hasil Uji Independent Sampel T-test

\begin{tabular}{llll}
\hline N-Gain & & $\begin{array}{l}\text { Equal Variances } \\
\text { Assumed }\end{array}$ & $\begin{array}{l}\text { Equal Variances } \\
\text { Not Assumed }\end{array}$ \\
\hline Levene's Test For & $\mathrm{F}$ & 1,604 & \\
Equality Of Variances & $\mathrm{Sig}$ & 0,210 & \\
\hline t-test for equality & $\mathrm{T}$ & 7,266 & 7,298 \\
of Means & $\mathrm{Df}$ & 63 & 59,376 \\
& Sig (2-tailed) & 0,000 & 0,000 \\
\hline
\end{tabular}

Berdasarkan uji Independent Sampel T-test yang terbaca dari nilai $\mathrm{t}_{\mathrm{hitung}}$ sebesar atas sebesar 7,266 sedangkan $t_{\text {tabel }}$ sebesar 0,2027. Nilai $t_{\text {hitung }}>t_{\text {tabel }}(7,266>$ $0,2027)$ dan signifikansi $(0,000<0,05)$ sehingga dapat disimpulkan bahwa $\mathrm{H}_{0}$ ditolak, maka dapat dikatakan terdapat perbedaan yang signifikan kemampuan berpikir kritis siswa pada kelas eksperimen dengan kelas kontrol. Hal tersebut sesuai dengan hipotesis yang telah diberikan.

\section{Pembahasan}

Pembelajaran yang dilakukan pada kelas eksperimen mengunakan blended learning berbasis schoology dengan model inkuiri terbimbing dan pada kelas kontrol pembelajaran konvensional. Blended learning yang digunakan dalam pembelajaran yaitu tipe ketiga yang dilakukan secara online learning - tatap muka - online learning dalam satu siklus pertemuan. Pada saat online learning menggunakan platform schoology. Schoology digunakan untuk media diskusi secara online.

Online learning yang dilakukan sebelum pembelajaran tatap muka melakukan pengamatan fenomena dan menentukan hipotesi dari masalah tersebut. Hal tersebut dilakukan dengan melihat video-video yang telah diberikan oleh guru pada platform schoology dan untuk memberikan hipotesis dilakukan secara diskusi pada kolom komentar. Melalui kegiatan yang dilakukan dengan pengamatan dan memberikan dugaan dapat meningkatkan kemampuan berpikir kritis [25].

Pada saat tatap muka dilakukan eksperimen dengan metode inkuiri terbimbing. Melalui kegiatan tersebut siswa dapat menemukan fakta-fakta kebenaran dari masalah tersebut dan berinteraksi sosial dengan teman sebayanya. Melalui metode eksperimen siswa belajar untuk menemukan jawaban dari permasalahan dan melalui siswa interaksi sosial siswa mampu meningkatkan kemampuan berpikir kritis siswa [26].

Online learning yang dilakukan setelah pembelajaran tatap muka melakukan diskusi soal-soal yang terkait dengan hasil eksperimen. Melalui diskusi soal tersebut siswa dapat memberikan jawaban yang tepat dan informasi yang di 
dapatkan dari hasil eksperimen sehingga membuat siswa memiliki jawaban yang dapat dipertanggung jawabkan yg dapat meningkatkan kemampuan berpikir kritis siswa [27]

Hasil $N$-Gain pada Uji Independent Sampel T-test bahwa kelas eksperimen memiliki nilai $N$-Gain 0,43 sedangkan kelas kontrol 0,10 . Selanjutnya didapatkan Uji Independent Sampel T-test dengan Asymp. Sig (2-tailed) >0,05 sehingga $\mathrm{H}_{0}$ ditolak maka dapat disimpulkan bahwa terdapat perbedaan rata-rata kemampuan berpikir kritis siswa kelas eksperimen dan kelas kontrol secara siginifikan.Artinya penerapan blended learning berbasis schoology memberikan pengaruh yang siginifikan terhadap kemampuan berpikir kritis.

Berdasarkan dari hasil angket yang diberikan kepada sisiwa setelah usai pembelajaran menggunakan blended learning bahwa banyak siswa yang tertarik dengan pembelajaran blended learning. Sistem pembelajaran yang mudah untuk diikuti sehingga memudahakan dalam proses belajar. Selebihnya, siswa termotivasi untuk belajar karena dapat dilakukan dimana saja dan kapan saja dan lebih mengetahui pemanfaatan teknologi yang dapat digunakan dalam proses pembelajaran namun memiliki kendala pada akses internet.

Berdasarkan hasil penelitian ini dapat dikatakan blended learning memiliki keunggulan yang baik untuk diterapkan dan dapat meningkatkan kemampuan berpikir kritis siswa. Hal tersebut sesuai dari hasil penelitian Herdiyana bahwa blended learning berbasis inkuiri terbimbing lebih praktis dan efektif untuk melatihkan kemampuan berpikir kritis siswa [28]. Selain itu menurut Lestari menyatakan pembelajaran melalui blended learning membuat siswa berpikir secara holistik dan dapat mampu memunculkan pertanyaan serta jawaban kritis siswa [29].

\section{KESIMPULAN}

Berdasarkan data hasil penelitian dapat disimpulkan bahwa terdapat pengaruh pembelajaran menggunakan blended learning berbasis schoology terhadap kemampuan berpikir kritis siswa secara signifikan. Artinya Kemampuan berpikir kritis kelas eksperimen lebih tinggi daripada kemampuan berpikir kritis kelas kontrol. Siswa juga memiliki kepuasan terhadap blended learning.

Berdasarkan penelitian yang telah dilakukan disarankan untuk peneliti dapat meneliti lebih lanjut mengenai hubungan blended learning terhadap motivasi belajar ataupun hasil belajar dengan taraf tinggi, sedang ataupun rendah. Peneliti juga harus memperhatikan koneksi internet untuk menunjang online learning.

\section{UCAPAN TERIMAKASIH}

Penulis mengucapkan terima kasih kepada Winda Wijayanti dan Tiara Dama Yanti yang telah mengizinkan untuk menggunakan produk penelitian terdahulu dalam penelitian ini. 


\section{DAFTAR PUSTAKA}

[1] TIMSS. 2015. Math Student Achivement Infographic Grade 4. Diakses dari http://timss2015.org/download-center. Diakses pada 28 Mei 2018

[2] OECD. 2016. Results Excellence and Equity In Education. OECD Publishing.

[3] Irawan, V.T., Sutadji, E. and Widyanti. 2017. Blended Learning Based On Schoology: Effort Of Improvement Learning Outcome And Practicum Chance In Vocational High School. Cogent Education. Volum 4, Hal.1-10.

[4] Mihai, A. and Christova, A. 2011. Teaching European Studies: A Blended Learning Aproach. Institute For European Studies (IES) - Vrije Universiteit Brussel (VUB). Belgium. International Journal of Emerging Technologies in Learning (iJET). Volum 6, Nomor 4, Hal. 22.

[5] Gozali, F. dan Billion, L. 2011. "Pemanfaatan Teknologi Open Source dalam Pengembangan Proses Belajar Jarak Jauh di Perguruan Tinggi”. Seminar Nasional Optimalisasi Pemanfaatan Aplikasi TI dalam Dunia Pendidikan.

[6] Smart, K., and Cappel, J. 2006. Students' Perceptions of Online Learning: AComparative Study. Journal of Information Technology Education. Volum 5, Hal. 21-0219.

[7] Collopy, R.M.B., and Arnold, J.M. 2009. To Blend or Not to Blend: Online and Blended Learning Environments in Undergraduate Teacher Education. Issues in Teacher Education. Volum 18, Nomor 2, Hal. 85-101.

[8] Aycock, A., Garnham, C. and Kaleta, R. 2002. Leassons Learned from the Hybrid Course Project. Teaching with Technology Today. Volum 8, Nomor 6, Hal. 9-21.

[9] Suana, Wayan., Maharta, Nengah. dan Nyeneng, I. D. P. 2017. Design And Implementation of Schoology Based Blended Learning Media For Basic Physic I Course. Journal Pendidikan IPA Indonesia Al-BiRuNi. Volum 6, Nomor 1, Hal.170-178.

[10] Sanjaya, Wina. 2010. Strategi Pembelajaran Berorientasi Standar Proses Pendidikan. Kencana, Jakarta.y

[11] Zain, R. A., Jumaidi. 2018. Effectiveness of guided inquiry based on blended learning in physics instruction to improve critical thinking skills of the senior high school student. Journal of Physics .

[12] Wartono., Huda, M. N., Batlolona, J. R. 2018. How Are The Physics Critical Thinking Skills of The Students Taught by Using Inquiry-Discovery Through Empirical and Theorethical Overview. EURASIA Journal of Mathematics, Science and Technology Education. Volume 14,Nomor 2, Hal. 691-697.

[13] Lederman, N. G., Lederman, J. S. and Antink, A. 2013. Nature Of Science And Scientific Inquiry As Contexts For The Learning Of Science And Achievement Of Scientific Literacy. International Journal Of Education In Mathematics, Science And Technology. Volum 1, Nomor 3, Hal.138-147.

[14] Wenning, C.J. 2011. The Levels of Inquiry Model of Science Teaching. Journal of Physics Teacher Education Online. Volum 6, Nomor 2, Hal. 9-16.

[15] Krulik, S., \& Rudnick. 1996. Innovative Taks To Improve Critical And Creative Thinking Skill. Developing Mathematical Reasoning in Grades. 
[16] Ennis, R. H. 1985. Critical Thinking. New Jersey : Prentice-Hall Inc.

[17] Lakovos, T. 2011. Critical and Creative Thinking in the English Language Classroom. International Journal of Humanities and Social Science. Volum 1, Nomor 8, Hal. 65-80.

[18] Oz, M., \& Memis, E., K. 2018. Effect of Multi Modal Representations on the Critical Thinking Skills of the Fifth Grade Students. International Journal of Progressive Education. Volume 4, Number 2 Hlm. 209-227

[19] Alvin, S. and Sicat. 2015. Enhancing College Students' Proficiency in Business Writing Via Schoology. International Journal of Education and Research. Volume 3, Nomor 1, Hal. 163-170.

[20] Keshta, A. S. and Harb. 2013. The Effectiveness Of A Blended Learning Program On Developing Palestinian Tenth Graders English Writing Skills. Journal of The Pennsylvania of Science. Volum 2, Nomor 6, Hal. 208-221.

[21] Biswas, Shampa. 2013. Schoology Supported Classroom Management: A Curriculum Review. Northwest Journal of Teacher Education Practices. Volum11, Nomor 2, Hal. 187-196.

[22] Dobre, Iuliana. 2015. Learning Management Systems for higher education an overview of available options for Higher Education Organizations. Socialand Behavioral Sciences. Volum 180, Hal. 313-320.

[23]. Trivedi, R.K., Mohd, Noor. dan Sharma, R. 2011. Proposed Framework For Open Source Based E-Learning Implementation In Uttarakhand. International Journal Of Engineering Research \& Technology. Volum 2, Hal. 2276-2277.

[24] Wijayanti, W., Maharta, N., \& Suana, W. 2017. Pengembangan Blended Learning Berbasis Learning Management System Pada Materi Listrik Dinamis. Journal Ilmiah Pendidikan Fisika Al-BiRuNi. Volume 6, Nomor 1, Hal. 1-12.

[25] Putra, P. D., A \& Sudarti. 2015. Pengembangan sistem E-Learning untuk meningkatkan keterampilan berpikir kritis Mahasiswa Pendidikan Fisika. Jurnal Fisika Indonesia. Volume 19 Nomor 55 hlm 45-48

[26] Vygosky, L.S. 1994. Mind in Society: The Development of HigerPsyhological Process. Cambride : Harvad University

[27] Andyana, G. P. 2012. Keterampilan Berpikir Kritis dan Pemahaman Konsep Siswa pada Model Siklus Belajar Hipotesis Deduktif. Jurnal Pendidikan dan Pengajaran. Volume 45 Nomor 3 Halaman 201-209.

[28] Herdiyana, Fitriani. 2017. Implementasi Perangkat Pembelajaran Blended Community of Inquiri untuk Melatihkan Kemampuan Berpikir Kritis Mahasiswa Calon Guru Biologi. Membangun Generasi Berkarakter Melalui Pembelajaran Inovatif. Seminar Nasional. IKIP Mataram.

[29] Lestari, Dian., Mulyani, Sri. and Susanti, R. 2016. Pengembangan Perangkat Blended Learning Sistem Saraf Manusia untuk Meningkatkan Keterampilan Berpikir Kritis. Journal of Innovation Science Education. Volum6, Nomor 1, Hal. 92. 